www.jmscr.igmpublication.org

Impact Factor 5.84

Index Copernicus Value: 71.58

ISSN (e)-2347-176x ISSN (p) 2455-0450

crossref DOI: _https://dx.doi.org/10.18535/jmscr/v5i9.130

Journal Of Medical Science And Clinical Research

IGM Publication

An official Publication of IGM Publication

\title{
Experimental Evaluation of Rasapanchak - A Narrative Review
}

Authors

\author{
Dr Santosh Kr Vishwakarma ${ }^{1}$, Dr Raman Ranjan ${ }^{2}$, Prof. V.S.Dubey ${ }^{3}$, \\ Prof. U. S. Chaturvedi ${ }^{4}$, Prof. A.K. Singh ${ }^{5}$ \\ ${ }^{1}$ Asst. Prof., Dravyaguna Dept., SRTACH, Gaya \\ 9304712033, Email: dr.santosh.ayu@gmail.com \\ ${ }^{2}$ MD (ay), AMO, GAD, Raigarh, Email: raman.ranjan27@gmail.com \\ ${ }^{3} \mathrm{HOD}$, Dravyaguna Dept., GACH, Patna \\ ${ }^{4}$ Principal, GACH, Begusarai \\ ${ }^{5}$ HOD, PG Dept., GACH, Patna
}

\begin{abstract}
Rasa, Vipaka, Guna,Virya and Prabhava are the five components of Rasapanchak and these are the basic descriptors of ayurvedic pharmacology, i.e. Dravyaguna Vigyana. Still many research works and dissertation are not being done on the basis of Rasapanchaka of the drug but the molecular basis is focused in prime, especially for the ethnomedicines which are not described in classics or if described their rasapanchaka is not specified. So there is a need of developing an experimental method to evaluate their rasapanchaka.

In Ayurvedic system of medicine the drug is used as whole, unlike modern system of medicine in which the fractional component or a synthesized molecule is used as a drug. On the other side a plant or any single drug contains numerous phytochemicals. Studying the pharmacological properties of single molecule or a class of molecule cannot solve the purpose in ayurvedic way but assessing the Rasadi padarth of the whole drug can put footmarks towards the basic principles of Ayurveda.

Many scholars across the globe have done many experimental studies to specify the rasa of a crude drug. The development of electronic tongue (e-tongue) with differential sensing is a major step towards assessing the rasa of a drug. Chromatography is another tool for the qualitative evaluation of a drug. Many attempts are being done to generate Botanical Reference material for different rasa present in a drug in the light of chromatographical fingerprinting. The discovery of taste receptors spread in extra oral locations like stomach, intestine, heart, adipose tissue etc. as a diffuse chemosensory system throws light on the several principals of ayurvedic pharmacology especially the rasapanchaka. Knowing the mechanism of activation and suppression of these extraoral taste receptors one can design and experimental model to derive the rasa of a particular drug.

Classical description of vipaka says that it is reflected in its effects. Taking this in consideration scholars hypothesised that Vipaka can be assessed by experimentally evaluationg the effects of a drug on the quantity of stool, urine and increase in proliferation of sperm cells.

Applying the law of thermodynamics virya are said to be the change in enthalpy. Exothermicity and endothermicity are shown experimentally in-vitro by usna and sheeta virya dravya respectively. Further thermal transduction exhibited by certain chemosensors present in various organs also falls in parallel with the two viryas described in Ayurveda.

Prabhava being 'achintya' or non derivable can't be generalized, but specific actions found in experimental studies which are not found in drugs with similar organoleptic characters can be considered as prabhava.

All these above experiments, hypothesis and botanical reference materials can be collectively used as a tool to evaluate the rasapanchaka of a drug. This review article is an attempt to narrate some of the important works done in this field.

Keywords: Rasapanchak, Ayurvedic pharmacology, Chromatography, Extraoral taste receptors, Thermodynamics, experimental evaluation.
\end{abstract}




\section{Introduction}

Plants are the major source of medicines used by the Ayurveda fraternity since beginning. The pharmacological parameter used by ayurvedic science to define the therapeutic attributes of a plant is rasapanchaka, which constitutes of Rasa, Guna, Vipaka, Virya and Prabhava. Molecular model doesn't falls in continuum with the ayurvedic principles.

Many researches and studies are done and the pharmacological mysteries are being solved with advancement of scientific techniques and development of sophisticated equipments. Rasapanchaka are not untouched topics of interest, but the works are discrete, evaluating any single or two component of rasapanchak.

This review is an effort to bring some of the important works, postulations and experimental designs together so that combinely they can give a rough picture of the method of experimental evaluation of rasapanchaka.

\section{Materials and Methods}

Various published articles concerning the evaluation of rasa, guna, vipaka, virya and prabhava i.e. rasapanchaka, in which the evaluation method is derived from the ayurvedic principles are searched and thoroughly reviewed. Articles stating the probable scientific mechanisms behind ayurvedic principles regarding rasapanchaka are also been searched and reviewed.

\section{Discussion}

Rasa: Ayurveda classifies rasa into six types, namely madhura(sweet), amla(sour), lavana (salty), katu(pungent), tikta(bitter), kashaya (astringent).

The exact technique of identification of rasa in the classical period is unknown. As many new plants being introduced as a drug for the treatment of many diseases there is a need to evaluate the plant in terms of ayurvedic pharmacological parameters. As far as the rasa is concerned many attempts has been done and few equipments are also developed or introduced in the field of
Ayurveda to identify the rasa present in a crude drug.

E-tongue or electronic tongue is a sophisticated instrument used by pharma industry to check the palatability of a drug for quality control. It works on the principle of differential sensing and simulates the gustatory and olfactory systems of mammals. These differential sensors when coupled with multivariate signal processing system can even assess the rasa (taste) of an unprocessed drug which usually contains thousands of different types of phytochemicals.

Spectroscopic metabolomics is an another approach to identify the chemical nature of a complex sample, by using Nuclear magnetic resonance(NMR), ultraviolet and Fourier transform infrared spectroscopy etc.

A different approach viz. chromatography was applied by various researchers in ascertaining the presence of a rasa in plant samples. Rasika H. Kohle, Rabinarayan Acharya and Vinay J. Shukla (2014) worked on the role of thin layer chromatography in ascertaining kashaya rasa in two plants which falls under samana pratyarabdha and vichitra pratyarabdha category. A botanical reference material (BRM) was thus developed for kashaya rasa. Similarily BRM for different rasa can be developed and these can serve as an experimental pathway for identification of rasa in any plant.

Further, in various studies, extraoral taste receptors were discovered resulting in affirmation of peripheral coding of taste. These extraoral oral taste receptors are found to be present in various locations like stomach, intestine, liver, pancreas, respiratory system, heart, brain, kidney, urinary bladder, adipose tissue, testis, ovary etc. and combinely form a diffuse chemosensory system. This discovery throws a new light revealing the basic pharmacological principles of Ayurveda. The generalized biological effect (dosha-dhatu karma etc.) of rasa on body in ayurvedic perspective was revealed and redefined in these works. The effects on the diffuse chemosensory system by different rasa can serve as a future 
model of experiments for the assessment of unknown rasa in a drug sample.

Vipaka: Vipaka is rasa expressed in assimilated food after digestion. Mainly two (guru or madhura and laghu or katu) or three (madhura, amla and katu) types of vipaka are explained in ayurvedic texts. Their effect (parimaan lakshanam) is said to be its identifying feature.

Dr. Hebbar proposed an animal model to assess the vipaka of an unknown drug or to reassess the vipaka of a classical drug. The basis is the effect of vipaka on dhatus described in classics. The proposed model constitutes of two groups of animals in which one group is administered with the test drug along with diet and the other control group is fed on the same diet as the test group without any drug. Measuring the quantity of faeces, quantity of urine for a certain period of time as well as studying the testicular histology after that period may reveal a significant variation in the two groups. The drug which shows increase in quantity of faeces, urine and spermatogenesis may be labeled as madhura vipaka and which decreases them may be labeled as katu vipaka.

Guna: Gunas have an important position in the physiological, pathological as well as pharmacological demarcation in the field of Ayurveda. There are 20 gunas called 'Gurvadi gunas' as per most of the ayurvedic classics. The doshas, which are basic physiological entities, are designated with some of the gurvadi gunas viz. the seven amsas of doshas. Further the pathological states are said to be due to vitiation of doshas characterized by increase or decrease in the gunas associated with it. The pharmacological entities like rasa, vipaka and virya are also assigned with gunas eg. Guru, snigdha and sheeeta guna of madhura rasa etc. Further the sadupkrama are also based upon the gunas eg. Langhane laghu, brimhane guru etc.

Therefore gunas are unseperable factors with each and every basis subjects of Ayurveda and this spreads a big area of experimental model that can be generated to assess the guna of a drug.
VIRYA: Mainly usna (hot) and sheeta (cold) are the two viryas described in dravyaguna and are said to be the main virtue by which drug exhibits its action. Many research workers demonstrated the exothermicity and endothermicity of different drugs experimentally with an inference that usna virya dravya exhibits exothermic reaction and sheeta virya dravya exhibits endothermic reaction. This opens the pathway for the in-vitro identification of virya of a drug.

In another experimental study it has been shown that hot-cold properties represent an important cultural filter connecting organoleptic characters and therapeutic uses of medicinal plants. This conclusion was made on the background that certain categories of chemo sensors e.g. transient receptor potential (TRP) may be involved which exhibit thermosensation transduction. When these are activated by certain phytochemicals, TRPs stimulate either a sensation of warmth or a sensation of cooling. So on the basis of hyperthermic and hypothermic effect on the chemosensors, viryas can be considered as energetic nature mediated by TRPs and can be a tool for evaluating the virya of a drug.

Prabhava: Being described as achintya (non derivable) virya, prabhava can't be derived by rasa, guna, vipaka and virya. But as phabhava exhibits well targeted therapeutic effects, can be assessed if any therapeutic effect is found to be not in linear with the rasa, guna, vipaka and virya or if such therapeutic action is not found in dravyas with similar organoleptic characters.

\section{Conclusion}

Certain experiments are successfully done to evaluate or ascertain the rasa of a drug. The use of differential sensing by electronic tongue is an important breakthrough in this field. Chromatographically developing the BRM for each rasa may give a novel method to assess the rasa in future. Effects on the extraoral taste receptors by different rasa may also serve as a future design for the rasa evaluation. For evaluation of vipaka animal model is postulated. 
Guna being diversely associated with physiological, pathological and pharmacological parameters may be a key point towards its experimental evaluation. Thermodynamically viryas can be specified by measuring the exothermic or endothermic nature of the drug. Prabhava being non derivable can be reckoned if a drug depicts an unusual pharmacodynamics.

There is a scarcity in the scientific insight into the vipaka and guna assessment by experimental models. More equipments or theories must be designed to ease the assessment of rasapanchaka on the experimental basis.

\section{References}

1. A critical review on the concept of drug as a whole; ISSN: 2322 - 0902 (p) ISSN: 2322 - 0910 (o) International Journal Of Ayurveda And Pharma Research | February 2017 | Vol 5 | Issue 2 56; Tatapudi Mahesh Babu, Ch. Ravi Kumar, A. Vijayalakshmi and V. Narasimha

2. Challenges and Scope for Assessment of Herbal (Ayurvedic) Drug Response: Ayurvedic Perspective; International Journal of Applied Ayurved Research ISSN: 2347- 6362; Pardeshi Raviraj, Ade Jaykumar, Hiremath Nandini and Raja Deepak

3. Extraoral Taste Receptor Discovery: New Light on Ayurvedic Pharmacology; Hindawi Evidence-Based Complementary and Alternative Medicine, Volume 2017, Article ID 5435831; Marilena Gilca and Dorin Dragos

4. Role of thin-layer chromatography in ascertaining Kashaya Rasa (astringent taste) in medicinal plants on the concept of Samana and Vichitra Pratyayarabdha principles of Ayurveda. Ayu 2014;35:17983. Kolhe RH, Acharya R and Shukla VJ

5. https://easyayurveda.com/2016/04/20/vipa ka-taste-conversion/ [cited 2016 April 20]. Available from: http://www.easyayurveda.com/
6. Importance of Guna Amongst Rasapanchaka; International Ayurvedic Medical Journal, ISSN:23205091; Karra Nishteswar

7. Endothermic Reaction For Veerya Analysis of Amalaki (Emblica Officinalis Gaertn.) An Experimental Study; PARIPEX - INDIAN JOURNAL OF RESEARCH; Volume : 3 | Issue : 10 | Oct 2014 ISSN - 2250-1991 139; Dr.Madhu Pathak and Dr. Satej Banne

8. Exothermic Reaction For Veerya Analysisof Rakta Punarnava (Boerhaviadiffusa Linn.) - An Experimental Study; International Journal of Medical Science and Clinical Inventions

9. Dr. Mahantkumar Naik P, Dr. Shraddha. U.Nayak Volume 1 issue 102014 page no. 555-558 ISSN: 2348-991X; 